\title{
HALOGEN AND AR GEOCHEMISTRY OF METASOMATIC MANTLE XENOLITHS FROM THE BULTFONTEIN PIPE (KIMBERLEY DISTRICT, SOUTH AFRICA)
}

Giuliani A., Kendrick M.A. and Phillips D.

School of Earth Sciences, The University of Melbourne, Parkville, 3010 Victoria, Australia

\section{INTRODUCTION}

Earth's halogen inventory is concentrated in the surface reservoirs of seawater and sediment. As a result, the halogens provide a sensitive indicator for estimating the extent to which surface volatiles are entrained by subduction and contribute to melting the mantle. Coupling halogen measurements with Ar isotope studies of mantle minerals may give further constraints on the subduction of volatile species. The $40 \mathrm{Ar} / 36 \mathrm{Ar}$ of modern air is constant ( $<$ " 296), whereas the mantle $40 \mathrm{Ar} / 36 \mathrm{Ar}$ is variable, but more radiogenic than modern air (i.e. the mantle has higher $40 \mathrm{Ar} / 36 \mathrm{Ar}$ because $40 \mathrm{Ar}$ is continuously produced by $40 \mathrm{~K}$ decay). Therefore, low 40Ar/36Ar ratios in pristine mantle minerals would support the subduction of atmospheric argon. Moreover, the radiogenic ingrowth of $40 \mathrm{Ar}$ in K-rich minerals (e.g. phlogopite) might provide a reliable geochronometer to date mantle events (Kelley and Wartho, 2000).

Estimates of halogen budgets and Ar isotopic values in the depleted and convecting mantle have been obtained previously from the analyses of oceanic basalts (e.g. Schilling et al., 1978; Graham, 2002) and diamond inclusions (e.g. Turner et al., 1990; Johnson et al., 2000). Diamonds offer the advantage of storing fluids that were present at the time of their crystallization, hence providing information on the volatile geochemistry of the ancient sub- continental mantle. Diamonds, however, are characterized by a wide range in halogen ratios (Burgess et al., 2009) and it could be argued that they are not entirely representative of the bulk sub- continental lithospheric mantle (SCLM). In contrast to diamonds, very few halogen analyses have been reported for minerals in mantle xenoliths (Johnson et al., 2000), which should provide more information on the behavior of halogens in the SCLM. A further advantage of mantle xenoliths is that combined petrological studies provide an important mineralogical, textural and geochemical framework for interpretation of halogen, Ar and $\mathrm{K}$ data.

In this study, we report preliminary petrological and halogen/Ar data of four mantle xenoliths from the Bultfontein kimberlite, Kimberley, South Africa. The samples include two MARID rocks, a phlogopite-bearing spinel lherzolite and a polymict breccia. Petrological studies indicate that the current xenoliths were affected by metasomatic enrichment prior to entrainment by the kimberlite magma. For some samples the metasomatic event took place early enough for the attainment of chemical equilibration; other xenoliths preserve unequilibrated features that indicate metasomatism of the xenolith immediately prior to entrainment by the kimberlite magma.

Our aim is to investigate the role of metasomatism in modifying the halogen/Ar signature of these samples and of the SCLM in 


\section{$10^{\text {th }}$ International Kimberlite Conference, Bangalore - 2012}

general. In addition, the halogen/Ar content of metasomatic phases provides insights into the contribution of subducted crust to the source of metasomatic fluids. The analyses of halogen concentrations in equilibrated hydrated and anhydrous phases from the same xenolith should constrain the extent to which halogens are fractionated by the crystallization of hydrous minerals such as phlogopite and amphibole. The investigation of mineral phases from different xenoliths that have differing textures and metasomatic styles will allow an assessment of halogen and noble gas contents associated with different mantle fluids. Finally, the results of this study provide insight into the occurrence of excess ${ }^{40} \mathrm{Ar}$ documented for fluids in diamonds (Turner et al., 1990) and metasomatic phlogopite from the SCLM (Phillips and Onstott, 1988), with notable implications for Ar-Ar dating of mantle processes.

\section{SAMPLES DESCRIPTION}

The samples we have investigated come from the Bultfontein Dumps, which comprise historical waste material from mining of the Bultfontein kimberlite (Kimberley district, South Africa). The xenoliths record different styles of metasomatism. While we cannot provide any pressure- temperature constraints for the MARID samples, thermobarometric calculations applied to the minerals of samples XM1/142 and DU-1 indicate depth of provenance between 75 and $95 \mathrm{~km}$.

\section{MARID ROCKS}

The samples XM1/331 and XM1/498 belong to the MARID (mica-amphibole-rutile-ilmenitediopside) suite of xenoliths (Dawson and Smith, 1977). The sample XM1/331 is composed by zones enriched in coarse-grained K-richterite amphibole with minor phlogopite, and zones enriched in coarse-grained, preferentially oriented phlogopite with minor clinopyroxene and K-richterite. Rutile, ilmenite, sphene and zircon are minor constituents of the sample, and calciterich veins cross the xenolith. The preservation of chemical heterogeneities in the mineral phases (e.g. zoning of phlogopite and K-richterite) suggest metasomatic enrichment of the xenolith prior to entrainment by the kimberlite melt. The xenolith XM1/498 displays coarse grained, anisotropic texture, characterized by alternating bands enriched in K- richterite and phlogopite, with minor ilmenite and rutile. Phlogopite inclusions are present in K-richterite, but not viceversa, and phlogopite occurs interstitially to K-richterite. This indicates that the crystallization of K-richterite started earlier than phlogopite, and the precipitation of phlogopite continued after K-richterite formation stopped. The most abundant minerals in both the MARID rocks are in textural equilibrium.

\section{Spinel-phlogopite Iherzolite and} polymict breccia

18 The xenolith XM1/142 is the off-cut of a coarse-grained, proto-granular, spinelphlogopite lherzolite. Olivine grains host inclusions of spinel and scarce fluid inclusions arranged along trails (healed fractures). Phlogopite is very abundant (up to about $10 \mathrm{vol} \%$ ), and is systematically associated with clinopyroxene. Phlogopite and clinopyroxene are of metasomatic origin, but they are in textural equilibrium with the older mineral phases.

The xenolith DU-1 is composed by veins enriched in blebs (up to $5 \mathrm{~cm}$ sized) of ilmenite emplaced in a spinel-phlogopite harzburgite wall rock. The ilmenite-rich veins include large $(>0.5$ $\mathrm{mm}$ ) xenogenic minerals (i.e. olivine, garnet, ortho- and clinopyroxene) of various provenance (e.g. harzburgitic, lherzolitic, eclogitic) set in a groundmass of finer-grained olivine, phlogopite, ilmenite, rutile and rare sulfides. The texture and mineralogy of these ilmenite-rich veins is typical of polymict breccias (e.g. Lawless et al., 1979). Broad chemical heterogeneity in 


\section{$10^{\text {th }}$ International Kimberlite Conference, Bangalore - 2012}

the polymict breccia xenolith suggests that i) metasomatism occurred immediately prior to the entrainment of the xenolith by the kimberlite magma, and ii) the metasomatic fluid was a primitive or precursor kimberlite melt. Therefore, this sample offers the possibility to investigate and compare minerals formed during kimberlite- related metasomatism, and phases characteristic of the harzburgite wall rock.

For the analysis of halogens, $\mathrm{K}$, Ar isotopes and naturally occurring heavy noble gases $(84 \mathrm{Kr}$, $129 \mathrm{Xe}$ and 130Xe) mineral separates were prepared of the following phases:

a. phlogopite and clinopyroxene of MARID sample XM1/331;

b. phlogopite and K-richterite of MARID sample XM1/498;

c. phlogopite and olivine of lherzolite XM1/142;

d. phlogopite and garnet of ilmenite-rich veins, and phlogopite and olivine of harzburgite wall rock in polymict breccia DU-1.

These samples therefore enable us to compare the composition of phlogopite between different metasomatic environments and compare the partitioning behavior of halogens between phlogopite, K-richterite, clinopyroxene and fluid inclusions trapped in olivine and garnet.

\section{NOBLE GAS AND HALOGEN GEOCHEMISTRY}

\section{Analytical method and results}

The halogens $(\mathrm{Cl}, \mathrm{Br}, \mathrm{I})$ were measured simultaneously with noble gas isotopes (40Ar, $36 \mathrm{Ar}, 84 \mathrm{Kr}$ and 129Xe) using 40Ar-39Ar methodology (Turner et al., 1990). High purity mineral separates were obtained by handpicking under a binocular microscope. The mineral separates were cleaned in an ultrasonic bath using distilled water and acetone. The samples were then irradiated for 42 hours in the McMaster Nuclear Reactor (Canada). The irradiated samples of phlogopite, K- richterite and clinopyroxene were loaded into a resistance furnace sample holder. Following bake out, to achieve ultra high vacuum, these minerals were analyzed using 20 minute heat-steps (400 and 1500 or $1600^{\circ} \mathrm{C}$ ). In contrast, the samples of olivine and garnet were loaded into modified Nupro valves and analyzed by in-vacuo crushing. Extracted noble gases were purified using SAES getter pumps and expanded into the MAP-215 noble gas mass spectrometer at the University of Melbourne for isotopic analysis. In vacuo crushing data for olivine and garnet are considered representative of fluid inclusions. Whereas stepped heating data for phlogopite, Krichterite and clinopyroxene are representative of bulk compositions that include the volatiles bonded to the mineral lattice, and stored in fluid inclusions. Finally, the measured $40 \mathrm{Ar}$ values have been corrected for radiogenic ingrowth due to $40 \mathrm{~K}$ decay since emplacement of the Bultfontein kimberlite at $84 \mathrm{Myr}$ (Clement et al., 1979). Some results of noble gas- halogen analyses are displayed in figures 1 and 2 .

\section{MARID ROCKS}

The phlogopites of MARID samples yield apparent 40Ar-39Ar ages within error (166 \pm 3 and $169 \pm 3$ Myr in XM1/331 and XM1/498 respectively). The clinopyroxene, where noble gases and halogens are mainly stored in fluid

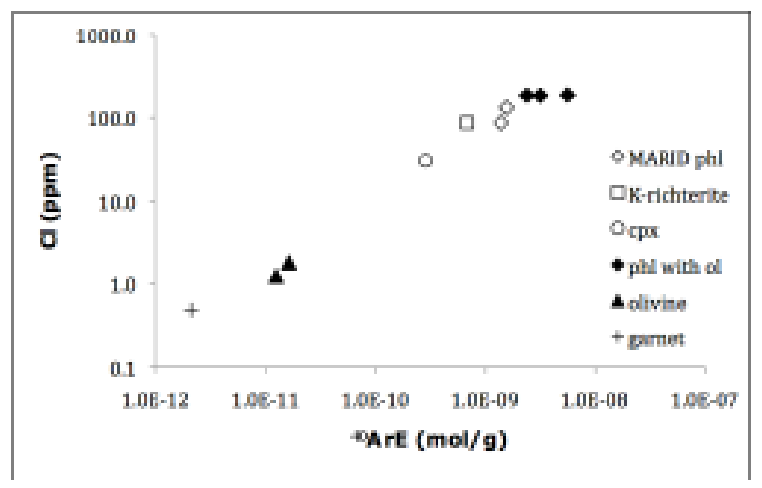

Figure 1. $\mathrm{Cl}$ vs $40 \mathrm{ArE}$ (i.e. $40 \mathrm{Ar}$ in excess to the atmospheric value) plot of the analyzed samples. 


\section{$10^{\text {th }}$ International Kimberlite Conference, Bangalore - 2012}

Figure 2. $\mathrm{I} / \mathrm{Cl}$ vs $\mathrm{Br} / \mathrm{Cl}$ ratio in the samples analyzed in this study and by Johnson et al. (2000).

inclusions, and K- richterite are significantly enriched in $\mathrm{Br}$ (127 and $218 \mathrm{ppb}$ respectively) and $\mathrm{Br} / \mathrm{Cl}$ ratio (fig.2) compared to phlogopite. In addition, phlogopite has lower $\mathrm{I} / \mathrm{Cl}$ ratio than clinopyroxene and K-richterite. The clinopyroxene and K-richterite samples investigated in this study have similar halogen ratios to the MARID diopsides and K-richterites that Johnson et al. (2000) analyzed by in-vacuo crushing (fig.2).

\section{Spinel-phlogopite Iherzolite and polymict breccia}

Phlogopites in the samples XM1/142 and DU-1 are distinctively enriched in $\mathrm{Cl}$ and $\mathrm{Br}$ (184$187 \mathrm{ppm}$ and 81-105 ppb) compared to the MARID phlogopites. However, the $\mathrm{Br} / \mathrm{Cl}$ ratios are very similar (fig.2).

The fluid inclusions hosted by both the olivine separates are extremely rich in I, but not in $\mathrm{Cl}$ and $\mathrm{Br}$. High $\mathrm{I} / \mathrm{Cl}$ ratios of $6.4 \times 10-3$ and $0.8 \times 10-3$ have been respectively reported for fluids in exhumed mantle wedge peridotite by Sumino et al.(2010), and for subducted serpentinites by Kendrick et al. (2011). However, these values remain far below the current molar I/Cl value of $26.5 \times 10^{-3}$, which represents an exceptional enrichment of I relative to $\mathrm{Cl}$ (fig.2). The ${ }^{130} \mathrm{Xe} /{ }^{36} \mathrm{Ar},{ }^{84} \mathrm{Kr} /{ }^{36} \mathrm{Ar}$ and ${ }^{40} \mathrm{Ar} /{ }^{39} \mathrm{Ar}(629 \pm 5$ and $1252 \pm 15$ in DU-1 and XM1/142 olivine respectively) ratios are higher than the modern air values, but ${ }^{40} \mathrm{Ar} /$
${ }^{39} \mathrm{Ar}$ is much lower than typical MORB mantle values of $>>10,000$ (Graham, 2002). Finally, the fluid inclusions in the analyzed garnets, which represent a mixture of garnet grains of diverse origin (harzburgitic, lherzolitic, eclogitic and megacrystic), have very low halogen concentrations (e.g. $\mathrm{Cl}=0.5$ ppm; fig.1). Taking together all the analyzed samples, we note a good correlation between $\mathrm{Cl}$ and 40ArE (fig.1), but a similar correlation is not present in $\mathrm{Br}-$ 40ArE and I-40ArE plots (not shown).

\section{PRELIMINARY INTERPRETATION}

\section{MARID rocks}

The minerals of xenolith XM1/498 preserve well-equilibrated textures and have uniform compositions. However, the MARID phases in xenolith XM1/331 have been overprinted by metasomatic alteration prior to entrainment by the

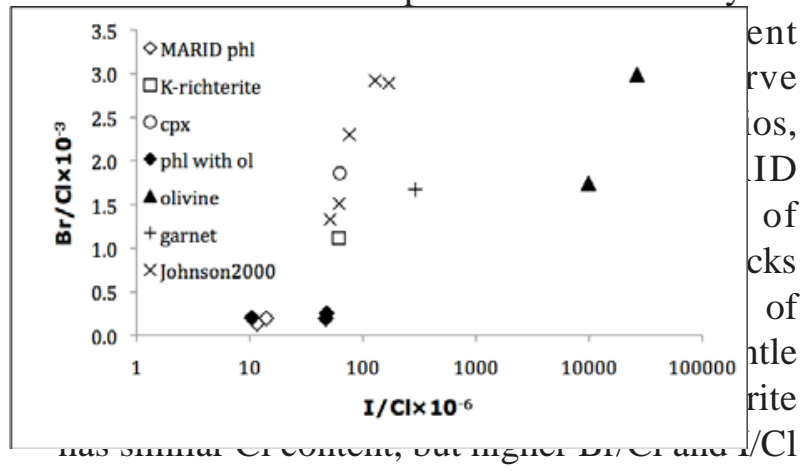

ratios compared to phlogopite (Figs 1 and 2). In comparison clinopyroxene, where halogens mainly reside in the fluid inclusions, has even higher $\mathrm{Br} / \mathrm{Cl}$ and $\mathrm{I} / \mathrm{Cl}$ ratios (fig.2). The $\mathrm{Br} / \mathrm{Cl}$ and I/Cl ratios of MARID phlogopite and K-richterite indicate that $\mathrm{Cl}$ is preferentially incorporated into phlogopite compared to the heavier halogens. At low water activity $\mathrm{Cl}$ is significantly incorporated in the structure of the crystallizing hydrous phase(s) (Sandford, 1981), whereas $\mathrm{Br} / \mathrm{Cl}$ and I/ $\mathrm{Cl}$ ratios increase in the residual fluid. Therefore, the highest $\mathrm{Br} / \mathrm{Cl}$ and $\mathrm{I} / \mathrm{Cl}$ ratios displayed by the fluid inclusions in XM1/331 clinopyroxene 


\section{$10^{\text {th }}$ International Kimberlite Conference, Bangalore - 2012}

suggest that the trapped fluid was residual after MARID metasomatism.

\section{Spinel-phlogopite lherzolite and polymict breccia}

The fluid inclusions in the olivines separated from the lherzolite (XM1/142) and the polymict breccia harzburgitic wall rock (DU1) have extremely high I abundances and I/Cl ratios. Elevated $\mathrm{I} / \mathrm{Cl}$ values in mantle wedge peridotites exhumed from depths of $\sim 100 \mathrm{~km}$ have been interpreted as the chemical heritage of subducted marine pore fluids (Sumino et al., 2010). One mechanism for deep subduction of pore fluid signatures is incorporation of the noble gases and halogens in to the lattice of the mineral serpentine (Kendrick et al., 2011). Following serpentine breakdown I-rich and Br-depleted fluids can be transported deep in the mantle within the fluid inclusions hosted by olivine and enstatite (Kendrick et al., 2011). Therefore, the extreme $\mathrm{I} / \mathrm{Cl}$ enrichment of the fluid inclusions trapped in olivine might testify to a deeply subducted, recycled fluid component escaping through the SCLM. This is in agreement with the relatively low $40 \mathrm{Ar} / 36 \mathrm{Ar}$ values of the analyzed olivines. The $130 \mathrm{Xe} / 36 \mathrm{Ar}$ vs $84 \mathrm{Kr} / 36 \mathrm{Ar}$ ratios of olivines fall close to the values of seawater and lithospheric mantle, but far from the air values, which is also consistent with a trapped fluid component.

The metasomatic phlogopite of the ilmenite-rich veins produced a $40 \mathrm{Ar}-39 \mathrm{Ar}$ apparent age of $227 \pm 4 \mathrm{My}$, which is remarkably older than the emplacement age of the Bultfontein kimberlite (84 Myr; Clement et al., 1979). However, the metasomatism of polymict breccias is well-known to be quasi- contemporaneous to xenolith entrainment by the kimberlite magma (e.g. Lawless et al., 1979). Therefore, we deduce that the fluids with high $\mathrm{I} / \mathrm{Cl}$, responsible for metasomatism, also introduced abundant excess $40 \mathrm{Ar}$. If further investigation will confirm this and early evidence (Phillips and Onstott, 1988), the logic interpretation would be that phlogopite is an unsuitable target for the Ar-Ar dating of mantle events.

Finally, the phlogopites in the lherzolite and polymict breccia samples have higher halogen than the MARID phlogopites. This might suggest that the fluids responsible for MARID metasomatism have a lower salinity than the fluids involved in the metasomatism of the other samples.

\section{CONCLUSIONS}

\section{We conclude that:}

a. halogen ratios $(\mathrm{Br} / \mathrm{Cl}$ and $\mathrm{I} / \mathrm{Cl})$ are fractionated by crystallization of different types of hydrous mineral (phlogopite and Krichterite) in the SCLM;

b. extreme iodine enrichment in mantle olivine, coupled with low 40Ar/36Ar ratio, suggests that halogens, and in general volatiles, are subducted and stored in the lithospheric mantle to depth e" 75-95 km;

c. the percolation of excess 40Ar-rich fluids in the mantle (Turner et al., 1990; Johnson et al., 2000) may affect the $40 \mathrm{Ar} / 36 \mathrm{Ar}$ of metasomatic phlogopite; therefore, the Ar-Ar dating of mantle phlogopite may produce ages without geological meaning.

\section{References}

Burgess, R., Cartigny, P., Harrison, D., Hobson, E., and Harris, J., 2009.

Volatile composition of microinclusions in diamonds from the Panda kimberlite, Canada: Implications for chemical and isotopic heterogeneity in the mantle. Geochimica et Cosmochimica Acta 73, 1779-1794.

Clement, C.R., Skinner, E.M.W., Hawthorne, J.B., Kleinjan, L., Allsopp, H.L., 1979. Precambrian ultramafic dykes with kimberlite affinities in the Kimberley area, in: Boyd, F.R., Meyer, H.O.A. 


\section{$10^{\text {th }}$ International Kimberlite Conference, Bangalore - 2012}

(Eds.), Kimberlites, Diatremes and Diamonds: their Geology, Petrology and Geochemistry. 2nd International Kimberlite Conference. American Geophysical Union, Washington, pp. 101-110.

Dawson, J. B. and Smith, J. V., 1977. The MARID (mica-amphibole-rutile- ilmenite-diopside) suite of xenoliths in kimberlite. Geochimica et Cosmochimica Acta 41, 309-333.

Graham, D.W., 2002, Noble Gas Isotope Geochemistry of Mid-Ocean Ridge and Ocean Island Basalts: Characterization of Mantle Source Reservoirs.

Reviews in Mineralogy and Geochemistry 47, 247317.

Johnson, L. H., Burgess, R., Turner, G., Milledge, H. J., and Harris, J. W., 2000. Noble gas and halogen geochemistry of mantle fluids: comparison of African and Canadian diamonds. Geochimica et Cosmochimica Acta 64, 717-732.

Kelley, S.P., and Wartho, J.A., 2000, Rapid Kimberlite Ascent and the Significance of Ar-Ar Ages in Xenolith Phlogopites. Science 289, 609- 611.

Kendrick, M. A., Scambelluri, M., Honda, M., and Phillips, D., 2011. High abundances of noble gas and chlorine delivered to the mantle by serpentinite subduction. Nature Geoscience, in press.
Lawless, P. J., Gurney, J. J., and Dawson, J. B., 1979. Polymict peridotites from the Bultfontein and De Beers mines, Kimberley, south Africa. In: Boyd, F. R. and Meyer, H. O. A. (Eds.), The mantle sample. Inclusions in kimberlite and other volcanics. 2nd International Kimberlte Conference. American Geophysical Union, Washington, pp. 154-155.

Phillips, D. and Onstott, T. C., 1988. Argon isotopic zoning in mantle phlogopite. Geology 16, 542546.

Schilling, J. G., Unni, C. K., and Bender, M. L., 1978. Origin of chlorine and bromine in the oceans. Nature 273, 631-636.

Sumino, H., Burgess, R., Mizukami, T., Wallis, S. R., Holland, G., and Ballentine, C. J., 2010. Seawaterderived noble gases and halogens preserved in exhumed mantle wedge peridotite. Earth and Planetary Science Letters 294, 163-172.

Sandford, R. F., 1981. Mineralogica and chemicla effects of hydration ractions and applications to serpentinization. American Mineralogist 66, 290297.

Turnen, G., Burgess, R., and Bannon, M., 1990.

8. Volatile-rich mantle fluids inferred from inclusions in diamond and mantle xenoliths. Nature 344, 653655. 